\title{
Introduction: Towards an Anthropology of Music and Dance Performances in a Transnational Context
}

\author{
Alice Aterianus-Owanga, Elina Djebbari and Monika Salzbrunn \\ Translator. Katherine Booth and Alexandra Poméon O'Neill
}

\section{(2) OpenEdition \\ Journals}

Electronic version

URL: https://journals.openedition.org/remi/14732

DOI: 10.4000/remi.14732

ISSN: $1777-5418$

This article is a translation of:

Introduction : Pistes pour une anthropologie des performances musico-chorégraphiques en contexte transnational - URL : https://journals.openedition.org/remi/13204 [fr]

\section{Publisher}

Université de Poitiers

\section{Printed version}

Date of publication: 1 December 2019

ISBN: 979-10-90426-65-8

ISSN: 0765-0752

\section{Electronic reference}

Alice Aterianus-Owanga, Elina Djebbari and Monika Salzbrunn, "Introduction: Towards an Anthropology of Music and Dance Performances in a Transnational Context", Revue européenne des migrations internationales [Online], vol. 35 - n⿳3 et 4 | 2019, Online since 01 March 2020, connection on 15 April 2022. URL: http://journals.openedition.org/remi/14732 ; DOI: https://doi.org/10.4000/remi. 14732

This text was automatically generated on 15 April 2022.

(c) Université de Poitiers 


\title{
Introduction: Towards an Anthropology of Music and Dance Performances in a Transnational Context
}

\author{
Alice Aterianus-Owanga, Elina Djebbari and Monika Salzbrunn \\ Translation : Katherine Booth and Alexandra Poméon O'Neill
}

The editors would like to thank Serjara Aleman, Federica Moretti and Ana Laura Rodriguez Quinones for their valuable assistance in editing the articles in this dossier, and Sarah Andrieu and Marie-Antoinette Hily for their insights and comments on previous versions of this introduction.

This introduction was translated from French to English with the support of the Institut des Sciences Sociales des Religions of the University of Lausanne.

1 Argentinean tango, Indian Bharatanatyam, Senegalese sabar, Mauritian sega, or Dominican bachata, each of these music and dance genres is linked, in the imaginaries of audiences and/or artists, to a "national" identification. Some are recognised as national heritage by a State, others are included on the UNESCO lists of Intangible Cultural Heritage of Humanity. Music and dance are thus frequently used by State organisations to convey nationalist ideologies or labelled in national terms by music industries in order to meet public expectations.

2 These national labels are in fact the product of complex historical constructions, at the intersection of state policies, population migration, and the intertwining of multiple identities (village, urban, ethnic, regional, community, religious, etc.). The Dominican bachata is an interesting example of these scalar variations at work in the production of a "national" genre: bachata, a music and partner dance, was the means of expression for those from rural areas who settled in the cities of the Dominican Republic during the first half of the $20^{\text {th }}$ century. This rhythm, initially associated with poor populations, regained popularity in the 1990s as a result of Dominican migration to the United States and the international success of several musicians. For Dominican 
immigrants, bachata became a mode of expression of their identity as part of the Dominican diaspora (Pacini Hernandez, 2014). Since the beginning of the $21^{\text {st }}$ century, bachata has conquered new international audiences, in particular through its commodification by the music industries, and its practice has become globalised - and transformed - through dance courses and festivals.

3 As illustrated by bachata, the association of a music-dance practice with a national identification takes place in several historical stages, and through mobility between different contexts. The national identities claimed through these practices do not conflict with the simultaneous existence of identifications with regional, trans-local or transnational communities, such as the "black nation" formed in the wake of hip-hop (Basu and Lemelle, 2006; Perry, 2008), or the "Latin" transcontinental community that invented itself in different places through salsa (Santos-Febres, 1997; Aparicio and Jáquez, 2003; Waxer, 2002). For these reasons, the field of music and dance practices provides a particularly heuristic approach to the examination of the interconnected registers and co-constructions between the local, the national and the transnational ${ }^{1}$.

This dossier ${ }^{2}$ focuses on the interconnections and intertwining of local, national and transnational dimensions that play out in the expression of identities. Drawing on ethnographic and historical research into various music-dance practices, the seven case studies deal respectively with salsa, kizomba, sabar, sega, sheikani, fandango and contemporary dance, and capture their modes of circulation between different spaces (Africa, Central and North America, Europe, Near and Middle East, Indian Ocean). The essays analyse how the experiences generated by music and dance influence the organisation and expression of registers of identification in these circulatory contexts.

Before presenting the articles that make up this dossier, we set out several theoretical references which guide their approaches to nationalism, transnationalism, and translocalism, followed by a reflection on the ways in which the anthropology of dance and music has worked with these different concepts.

\section{National, Transnational and Trans-local: Overcoming "Methodological Nationalism"}

6 Nationalism has long been regarded as a European phenomenon mainly addressed by historians (Thiesse, 1999), referring to a sense of belonging to an "imagined community" (Anderson, 1983), historically constructed on the basis of a territory, a State and possibly an ethnic identification (Gellner, 1989; Hobsbawm, 1992). The nation was then thought to be the result of a process of homogenisation linked to industrial modernity, and the culmination of nationalist movements promoted through writings and the media (Anderson, 1983).

7 From the 1990s onwards, research in the field of social sciences conducted on other continents provided alternative approaches: first of all, they revealed the diversity of the modes of emergence of nations and models used in this process, particularly in Latin America (Hébrard, 1996; Annino von Dusek and Guerra, 2003; Chasteen and Castro-Klarén, 2003); they also highlighted the heterogeneity of national narratives, beyond the sole perspectives of intellectual elites (Bhabha, 1990), and discussed the importance of regionalisms in national constructions (Thiesse, 2014). These studies demonstrated that, in addition to literature, painting and music, the rise of 
nationalisms was also based on the register of festivals, performances and dances (Hobsbawm and Ranger, 2006; Guss, 2000; Wade, 2000). Finally, studies on migration helped to look at nationalism beyond territory and the nation-state, showing how a sense of community developed in migratory or diaspora situations (Kastoryano, 2006).

In parallel to these new conceptions of nationalism, Nina Glick Schiller, Linda Basch and Christina Blanc-Szanton (1992) developed the idea that migratory trajectories are not synonymous with uprooting, but rather with taking root in both the host country and the country of origin. By studying migration between New York, Saint Vincent, Grenada, Haiti and the Philippines, they showed that "transmigrants" were involved in economic, political, social or religious activities linking their different social universes of reference, contributing thereby to the creation of transnational social fields.

Beyond polemics on the novelty of the phenomenon ${ }^{3}$ and its characteristics, this "transnational turn" in social sciences has made it possible to rethink the links between national and transnational. It has highlighted the importance of regional scales in processes of articulation between "local" and "global" and has made the understanding of intermediate scales more complex (Trémon, 2012) ${ }^{5}$. In this perspective, the work of Ludger Pries (1996) contributed to clarifying the concept of relational space, which is at the centre of his reflections on transnational social spaces ${ }^{6}$. In contrast to studies that view the modern world in terms of fluidity, liquidity and decline of nation-states (Appadurai, 1996; Bauman, 2013), Glick Schiller and Fouron's research (2001) demonstrated the ramifications of the nation-state that are woven into the transnational, the existence of "long-distance nationalisms" and the ethnicity claims of diaspora populations. Sainsaulieu, Salzbrunn and Amiotte-Suchet (2010) have shown that the strengthening of borders and claims of community belonging do not run counter to broader societal loyalties; on the contrary, these different levels of identification seem to co-construct and mutually nourish each other. The increasing complexity of circulation and identification networks has thus made it possible to reexamine national reconfigurations in a transnational world.

Recognising the ideological and epistemological implications of the "transnational turn", Nina Glick Schiller and Ayşe Çağlar (2011) have criticised it, calling for an effort to "localise migration" in order to re-situate the effects of local anchoring and the way they change urban environments. The questioning of theories of "transnationalisation" and their limitations in considering specific territorial anchoring has led to the development of the concepts of "multi-local" and "trans-local". The translocal approach makes it possible to consider that networks and circulation, in a globalised world, are concretely organised in and between specific localities rather than between abstract national spaces. It also emphasises the importance of the local context in which individuals who migrate are situated, with the national framework becoming a "second-order" referent with respect to the place where they live, and nationality an administrative "label" rather than a dimension that is experienced intimately (Conradson and McKay, 2007: 269). Monika Salzbrunn (2011: 171) offers a definition of trans-local social spaces that takes into account sources of identification and practices from local and global reference systems. Migrants are not only influenced by these trans-local references, they, in turn, have an impact on the evolution of their local environment. Trans-local social spaces thus accommodate multiple affiliations that go beyond the national framework alone, and which can be seen when we consider the local roots of practices, particularly artistic and festive practices (Salzbrunn, 2011). 
11 By putting the issue of oscillation between nationalisms, transnationalism and translocality at the centre of discussions, our dossier brings new perspectives to the existing literature on the relationship between dances and national identities.

\section{Dances and (Trans)nationalisms}

Anthropology has clearly exposed the role of music and dance practices in the production of nationalisms, in various continents and ideological or historical contexts (Shay, 2002; Castaldi, 2006; Buckland, 2007; Andrieu, 2009; Djebbari, 2013; Gibert, 2014; Franco, 2015; Aterianus-Owanga, 2017). Kelly Askew (2002) underlined that in Tanzania, dance and music groups contributed significantly to the emergence of political and national consciousness at the time of independence. On the island of Java, Felicia Hughes-Freeland sought to reconstruct the long history of court dances and their invention as a tradition consistent with national rhetoric, dance becoming "part of the incorporated and imagined community that is the nation-state" (Hughes-Freeland, 2008: 17). In her research in Burkina Faso, Sarah Andrieu used the study of cultural policies and performances of national identity to show how, even in contexts of strong state control, individuals continuously create dance traditions that are alternative to the national project (Andrieu, 2007). This field of anthropological research has thus given music and dance creations the status of relevant objects with regards to the understanding of various modalities of invention and staging of the nation.

13 More recently, scientific interest for music and dance practices in migration has opened up new issues in relation to the links between the making of identities through the arts and forms of transnationalism ${ }^{7}$, while at the same time highlighting the linkages between transnational and trans-local dimensions. In their comparative study on networks of musicians in Casablanca and Antananarivo, for example, Nadia Kiwan and Ulrike Meinhof (2011) described the existence of musical migration linked by certain cities, which they consider to be trans-local and transnational "hubs".

The articles in this dossier discuss the sometimes paradoxical, but often complementary, linkages and interconnections between nationalisms and transnationalisms arising from the circulation of music-dance genres. While building on the existing literature, they are the result of innovative scientific approaches. The first is to focus mainly on dance, while taking into account the musical dimension. In this respect, the dossier offers a significant contribution to French-speaking social sciences, which have rarely provided comparative studies and collective works questioning identity processes at work in the globalisation of dance practices ${ }^{8}$ (as compared to projects recently published in the field of music ${ }^{9}$ ). The studies explore music and dance together in their respective fields, while emphasising the role of corporeal engagement in the development of a sense of belonging. They link these two fields which, although they do not circulate in the same way (Apprill, 2015), benefit from being explored together for a number of reasons: first, because many terms refer to both dance and music, such as, among those considered in this dossier, sabar, salsa, kizomba, sega, fandango, sheikhani; secondly, because several performances or festivities observed combine dance and music, and are in fact based on a "sensorial multimodality" (Guillebaud, 2014); finally, because actors of these genres - whether amateurs or professionals - frequently interact in interconnected networks, particularly in global 
markets. In approaching the objects under examination, we therefore designate them by the terms "genres" or "music-dance performances".

The second approach consists in considering at the same time the national/ transnational/trans-local triad, concepts which turn out to be inseparable in these contexts of circulation of performances. The articles in this dossier discuss the various methodological and theoretical tools that can be used to go beyond the national/ transnational/trans-local dichotomies, to reflect instead on circulatory systems and multiple identities that are implemented and interact through music and dance.

\section{Dancing Stateless Nations}

16 A series of articles in this dossier describe the crafting of nationalisms through dance developing outside the State: Ana Rodriguez analyses how the creation of a contemporary dance scene in Palestine accompanies the emergence of a sense of belonging and common struggles among Palestinian youth. Acting as a catalyst of integration in transnational circulations, contemporary dance enables dancers involved in this practice to discover themselves as Palestinians in the world. The author adopts a methodological starting point of life trajectories to underline the way in which the insertion of certain individuals within the "transnational social space" of contemporary dance shapes subjectivities and a sense of belonging to an extended Palestinian nation. In this context, the nation is played out without a State, and the borders that delimit it are governed to a much greater extent by encounters with otherness (European or Israeli) and the awareness of transnational solidarity than by a notion of corresponding to a geographical territory and a sovereign State.

17 Another example of these stateless nationalisms embodied in dance can be found in Assyrian sheikani dances. From a multi-sited fieldwork in North America, Nadia Younan examines festivals where this dance is performed by the Assyrian diaspora, a "transnational community on two accounts - first in its homeland, then in the diaspora" according to the author. Firstly, explanations provided by actors on the genesis of sheikani dance are a medium for passing on mythical stories about Assyrian history; secondly, hours spent dancing in groups lead to a physical and emotional identification with an Assyrian national community, which is defined not so much by its attachment to a land of origin as by the idea of a "transglobal rhizomatic nation" (Laguerre, 2009 cited by Younan).

18 These two articles highlight various forms of transnational circulation of dance performances: on the one hand, a global expression which has become the driver of identification with a national resistance; on the other, an essentially community-based dance reconstructed in the diaspora. In both cases, confrontation with the transnational field is not the reason for a fragmentation of identity for the individuals involved; on the contrary, dance moments create a specific social space, which consolidates the memory of a lost homeland, or feeds the need for recognition as a community. Dance performances form and perpetuate national attachments "from below", in situations where there is no nation-state or cultural policies from above. 


\section{Scale Variations and Identity Affiliations}

19 The articles by Églantine Gauthier on Mauritian sega and Christian Rinaudo on Mexican fandango discuss interconnections between nationalism and transnationalism using a historical perspective and looking at variations in scale (regional, national and transnational) that contribute to shaping, experiencing, or representing "national" identifications through music and dance.

20 Églantine Gauthier focuses on sega in Mauritius, a postcolonial island nation. Looking back at the first writings about this performance, she shows how this music-dance genre was first identified from a colonial viewpoint as a "black" racial act, then gradually as a "Creole" cultural expression associated with the memory of slavery. The idea of a typically Mauritian community genre was thus constructed through circulation on the trans-oceanic and transnational routes of the colonial empires. With the rise of music industries after independence, sega then became a national emblem which was supposed to embody the full "multicultural" Mauritian nation, marked both by national cultural and remembrance policies, and by the exotic representations conveyed with the expansion of tourism. The last phase of the construction of sega examined by Églantine Gauthier is that of the contemporary migration of the Mauritian diaspora in France, for whom the appropriation of different variants of sega dance and music is the medium for the creation of a transgenerational Mauritian community. Taking into account the transnational over the long-term sheds light on the interconnection between different scales and historical periods that shape this musicdance genre. An approach in terms of connected history (Minard, 2013) prompts attention to be paid to the circulation and intersection of perceptions through which the various registers of belonging are produced, superimposed or juxtaposed.

Christian Rinaudo looks at music and dance from the Mexican Sotavento region using this long-term perspective. He examines the three "ages" of fandango, between local festival, performance of the Mestizo nation, and the cross-border festive experience in contexts of migration. He shows that although diachronic and multi-scalar analysis is essential to understand the multiple definitions and uses of this music-dance event, it is not sufficient: beyond the system of scales, "the points of linkage and tension between these spheres of action" (Rinaudo) also require examination. In this case, they reveal the transformation of certain myths on the origin of the fandango, the rejection of certain initial labels or the rupture with mobilisation networks that were once linked to it in other contexts. The article thus highlights the way in which the same music genre conveys changing senses of belonging and communality depending on the spaces in which it moves, in a permanent dynamic redefining the relationships between scales and spheres of action (local, national and transnational).

These examples thus demonstrate the extent to which the spatial movements and social situations brought about by dance constitute a fertile subject to nourish epistemological reflection on the issue of scales. The transnational anthropology of dance is a powerful tool for analysing processes of understanding the variability of scales, by empirically describing changes in the identification and definition of social space arising from the circulation of practices on a space/time axis.

Beyond this observation, other genres discussed in this dossier show how transnational circulations are also at the origin of social tensions and power relations. 


\section{Power Relations and Cultural Property in Globalisation}

Alice Aterianus-Owanga's article on sabar and Livia Jiménez Sedano's article on kizomba show how the identity affiliations claimed around certain repertoires are the subject of issues related to power and competition, reflecting a context of commodification of cultural goods and identities (Appadurai, 1996). The authors use various conceptual tools and theoretical approaches to examine these assertions of belonging; in particular, theories of identity, ethnicity and borders make it possible to understand the power issues underlying the global circulation of certain practices.

Alice Aterianus-Owanga studies the logics of inclusion and exclusion within a "Senegalese community" that are played out in the teaching of sabar dance in Europe. After retracing the gradual process of labelling of this performance, between Wolof ethnicity and the Senegalese nation, she explores the educational methods invented by artists who have migrated to Europe to make this repertoire accessible to different audiences, while conveying a form of belonging to their Senegalese origin. She describes the existence of polemics around the cultural ownership of sabar, and the forms of retention and control of knowledge about dance which they entail. She then analyses how the maintenance of borders between social groups and between cultural repertoires, some of which are claimed to be owned by certain groups, is linked to power relations and inequalities rooted in history and the post-colonial situation. Depending on encounters, contexts and power issues, sabar is sometimes presented as a marker of cultural boundaries, sometimes as a means of building a bridge across these boundaries.

Livia Jiménez Sedano also addresses polemics and conflicts of legitimacy raised by the global commodification of a cultural practice, but starting from a genre, kizomba, whose origins are unclear and scattered across several countries. This partner dance, which is today practised in cities throughout the world, was born out of multiple influences, from Angola, Cape Verde and Portugal. Various actors claim their contribution to its genesis and dissemination. By describing debates on the supposed origins of the practice, the author highlights various registers of legitimisation and identification, on national (Angolan), continental (African) or transnational (in Portuguese-speaking areas) bases. Thus, she shows how the transnational circulation of kizomba preceded its appropriation as a national brand, in this case by Angola.

By exploring the various scales of localisation of music and dance, the articles show how circulation and spatial anchoring respond to each other and feed exchanges between different registers of identity.

\section{Circulation and Anchoring}

The circulation of music and dance is generally accompanied by processes of anchoring and re-anchoring in the various spaces through which they pass (Andrieu and Olivier, 2017). In addition to links that dance and music can maintain with a physical space in discourse and practice, several articles in this dossier show that performances also provide the opportunity to (re)position oneself mentally and symbolically in space (Stokes, 1994). 

identity and circulation between spatial scales by proposing the concept of "transpolitanism". In support of her comparative research on the appropriation of salsa in Benin and Ghana, she develops this concept to better grasp the links between "transnational" and "trans-local" scales at work in the construction of identity affiliations. By focusing on temporary mobilities, repeated at regular intervals and carried out for a practice which has an urban context as its setting, the aim is to identify networks of interconnection from city to city, from the point of view of "lifestyle". In light of this paradigm, differentiated processes of appropriation of salsa in Benin and Ghana reveal the heterogeneity of practices and their respective anchoring in contexts shaped by mobile individuals in constant interaction, both on the dance floor and in social networks.

Wether through "transpolitan" mobility from city to city in West Africa (Djebbari) from sabar parties in Dakar to European gymnasiums (Aterianus-Owanga), or from island to island - all the way to the Ile-de-France (Gauthier), the ethnographies provided in the dossier illustrate how the local anchoring of transnational practices leads to systems of identification and feelings of belonging that reinforce or, on the contrary, circumvent the national referent. In her study on the re-anchoring of sega by the Mauritian diaspora in France, Églantine Gauthier shows that the co-presence of insular music-dance genres produces competition and/or alliances, particularly with the Reunionese people. This new context replays Indian-oceanic dynamics and questions in a new way the modalities of cultural belonging in a diasporic situation.

Moreover, the music and dance approach to the transnational circuits of diasporas and tourism sometimes follows pre-existing circulatory rationales. Livia Jiménez Sedano confirms this observation by explaining how the development of kizomba took place in already well-established transnational channels, notably those of salsa. Elina Djebbari shows that the process of anchoring salsa in West African metropoles has been supported by networks connected from city to city by the circulation of dancers.

The joint processes of deterritorialisation and reterritorialisation brought about by transnational circulation have an impact not only on their potential renationalisation, but also on the enhancement of a site-specific narrative of origins. As Yves Raibaud puts it, "the mobility and circulation of dances symmetrically question the determination of geographical imaginaries" (2015: 15). Christian Rinaudo thus shows how the city of Tlacotalpan has been identified as the "cradle" of jarocho son, forcing transnational actors of this practice to return to "recharge" in order to preserve their legitimacy. In the study of educational methodologies developed in the sabar community in Europe, Alice Aterianus-Owanga reveals how the regular return of dancers to Senegal is a means of remaining connected to "the source of knowledge" in order to nourish their teaching in Europe. These dynamics of cultural regeneration therefore lead to the development of further circulation and to music and dance practice tourism (Raout, 2009). 


\section{The Space-time of Performance: Bodies, Emotions and Individuality}

33 The articles in this dossier suggest that transnational circulations and affiliations benefit from being considered in terms of the particular space-times of performance: on festival stages (Rodriguez, Djebbari), in Lisbon nightclubs (Sedano) or European dance studios (Aterianus-Owanga), in associative and community meetings (Younan, Rinaudo), and even on the buses taking Mauritians from Île-de-France to the Pinterville pilgrimage (Gauthier). The ethnographies of these spaces offer localised perspectives, in short-term temporalities.

In this respect, research conducted and presented in this dossier argues in favour of taking into account the materiality of these phenomena of identity performance and their anchoring in given space-times, in the light of a reading of the "event" (AmiotteSuchet and Salzbrunn, 2019). Because of the centrality of the sensory and corporeal involvement required, dance constitutes a means of accessing a concrete and incorporated dimension of variations in identity scales. Observing the performance while considering the potentially disruptive nature of any event, and following its preparation and reception, makes it possible to detect the staging of ethnic or national identities, but also to perceive the subjectivities of individuals who create and experience these performances.

Far from being disembodied, the flows of cultural globalisation are mediated by individuals who make their bodies the vector of (trans)nationalisation processes of music-dance genres (Reed, 2016). Taking into account the role of Mexican activists in the introduction of jarocho son to the United States, Christian Rinaudo exposes how transnational networks are developed from localised individual initiatives. By paying attention to dance through individual trajectories, Ana Rodriguez emphasises the subjective and sensory dimension of feelings of belonging and their evolution over time. By evoking the discomfort felt by Maria, a Palestinian dancer, in her physical interactions with Israeli dancers, she brings up the intimate dimension of feelings of belonging. Nadia Younan's article also captures these emotional responses by addressing how sheikhani dance and music generate emotions both in dancers and those who attend performance situations. Taking into account the role of the body and emotions in performance situations reveals a "privileged mode of expression of multiplicity" of identity (Djebbari).

This vision includes the backstage to the event, the before and after, as well as the full range of adjacent cognitive elements: from the Mauritian culinary smells on the square in front of the church in Pinterville (Gauthier) to the pain of the body that has danced too much (Rinaudo), emerge the experienced and emotional aspects of feelings of belonging. These sensory approaches to time and space created by the performance bear witness to the complex mechanisms at play at the macro level. The articles then explain how individual subjectivities and registers of identification are co-constructed during music and dance performance, particularly in the emotional interpretation it elicits (Stokes, 2010).

While anthropological theories often struggle to account for the plasticity, the ephemeral and moving dimension of feelings of belonging and identification, the description of dance situations and the interviews which accompany them enable us to 
grasp the role of the body, movement and kinaesthetic connection in developing a sense of community. Several anthropological studies on partner dances emphasise the importance of "connection" and provide a detailed description of sensations and the states of emotional transport and transcendence that certain dances convey (Davis, 2015: 69), in relation to Turner's concept of liminality (Turner, 1987). Other studies address the feelings of belonging brought about by performance in terms of "emotional community" in order to capture this ephemeral, liminal and sensory dimension of belonging in dance (Aterianus-Owanga, 2018). It is within this ephemeral liminality that the invisible bonds of "communitas" are woven and that individuals manage to give substance to imaginaries of the nation or of a common form of spirituality, especially in a religious context: songs, accompanied by collective physical movements or even dances, practised by members of Sufi brotherhoods, especially the Mourides or members of the Naqshbandiyya order, aim at forgetting the self in order to reach a state of trance that brings them closer to the divine (Salzbrunn, 2019). In a migratory context, the musical aspect of these religious practices is constantly evolving, adapting to the material, spatial and political conditions of places of residence or passage (Salzbrunn, 2017). The circulation of musical practices in a religious or secular context is often accompanied by the dissemination of recordings using various media.

\section{Internet, Media and the Making of "Online" Identities}

38 In parallel to the liminal space-time of performance, music and dance practices circulate via social networks and their audio-visual recordings often serve as a learning model for people who have not attended these performances or celebrations in the country of origin. Reflection on spatial-temporal scales and circulations is pursued in this dossier by taking into account the significance of the Internet, social networks and video media in the relationship between circulations of music and dance forms and registers of appropriation and identification. While the circulation of music-dance genres, artists and identifications is ancient, the speed with which images, representations, music and choreography models circulate via social networks has increased considerably, thus modifying to the same extent the adaptations and hybridisations of these practices.

Several recent studies have shown the central role of the Internet in maintaining and/ or rediscovering transnational communicational links and national identity referents, particularly in diaspora situations (Ignacio, 2005; Hiller and Franz, 2004; Lysloff, 2003). With regard to music and dance practices, authors such as Jung (2014), Shipley (2013), Novak (2011), Djebbari (2019) have observed the extent to which the circulation of videos on the Internet, their availability and storage on social networks and downloading platforms have generated new modes of consumption of music and dance ${ }^{10}$. This accelerated expansion of communication technologies also represents a means of dealing with the physical obstacles encountered by a great many artists on administrative grounds (visa refusals).

Without forming a central element of the reflections presented in this dossier, videos broadcast on YouTube and social networks are used in the analyses as data related to the various fields covered. Ana Rodriguez points to the alternative, even subversive, circulatory possibilities that new media allow in the digital era, explaining that the use of video tools makes it possible to counter the immobility imposed by visa refusals. 
Alice Aterianus-Owanga highlights the way in which the social network is used as a medium in its own right to convey the expression of cultural and national identities, opening her text by quoting a message written on Facebook by a sabar dancer at the end of a dance workshop. Livia Jiménez Sedano attributes the speed of the global spread of kizomba in part to its visibility and accessibility on platforms such as YouTube and Facebook. Other facets of the link between video medium and digital circulation are analysed: among others, a video montage telescoping sabar performances between "white vultures" and "authentic African women"; video clips produced by Mauritian sega artists as contributing to the staging of an idealised national multiculturalism; promotional materials produced by the Angolan government such as the Kizomba Nation web platform. Nadia Younan devotes a whole section of her article to the "online" making of the Assyrian nation through the communication tools offered by the Internet. By studying how sheikhani dance is consumed through repeated viewing of videos on YouTube, she introduces an additional dimension. Dance is no longer limited to a specific space and time of performance: it is available online at any time, and the Internet provides a forum for expression to Assyrian commonality, in particular through the commentary space alongside the online videos.

\section{Conclusion}

41 The anthropological approach put forward in this dossier feeds reflection on the complex intertwining of the processes of (trans)nationalisation and trans-localisation by studying them together. The seven articles highlight the heterogeneity of the circulatory dynamics of music-dance genres, each rooted in specific historicities and interconnected spaces. These ethnographies of performances in circulation produce original readings of the phenomena of cultural globalisation, and the authors' theorising efforts offer several tools (methodological and conceptual) to go beyond the binarism of national/transnational, in particular by showing the importance of the local. Linking the local to transnational references is not contradictory but, on the contrary, often goes hand in hand.

Firstly, the observation of the mobility of festivals and dance situations shows the dialogue between two types of scales on which the intermediate levels of the national/ transnational binomial are based. On the one hand, the circulation of dances accompanies the definition of spatial scales, at the level of cities, regions, nations, and trans-local, transoceanic or transcontinental social spaces; on the other hand, the practice of dances mobilises in situation scales of identification and belonging, between ethnicity, regionalism, national diaspora communities, or groups attached to translocal spaces (real or imagined). The articles show how dance, by playing on time, space, sensations and individuality, encourages more than other practices the encounter between these two registers of scales (spatial and identity), which intersect without merging.

The other main value of this dossier is to explain how these dances in global circulation constitute a vehicle for the formation of social spaces, links of commonality and specific networks. As these music-dance genres circulate, they convey particular norms and "conventions" (Becker, 1988). The systems of meaning, codes and knowledge 
governing these dances feed off the localities to which they travel, just as they transform them.

Finally, this dossier makes it possible to re-examine the way in which the registers of identification combine in a system of anchoring and circulation, but also, and above all, in moments of situated performance. The approach through dance situations shows that this intertwining of scales is expressed in bodies, emotions and sensations. The attention to bodies and movements represents a methodological tool to go beyond the question of meaning and to understand these systems, sometimes contradictory, but often complementary, of intertwining multiple identities that individuals operate while dancing.

\section{BIBLIOGRAPHY}

Amiotte-Suchet Laurent et Salzbrunn Monika (Éds.) (2019) L'événement (im)prévisible. Mobilisations politiques et dynamiques religieuses, Paris, Éditions Beauchesne.

Anderson Benedict (1983) Imagined Communities: Reflections on the Origin and Spread of Nationalism, London, Verso.

Andrieu Sarah (2009) Le spectacle des traditions. Analyse anthropologique des processus de spectacularisation des danses au Burkina Faso, Thèse de doctorat en Anthropologie sous la direction de Bruno Martinelli, Université de Provence Aix-Marseille.

Andrieu Sarah (2007) La mise en spectacle de l'identité nationale. Une analyse des politiques culturelles au Burkina Faso, Journal des anthropologues, HS, pp. 89-103.

Andrieu Sarah et Olivier Emmanuelle (Éds.) (2017) Création artistique et imaginaires de la globalisation, Paris, Hermann, 380 p.

Annino von Dusek Antonio y Guerra François-Xavier (Eds.) (2003) Inventando la nación: Iberoamérica siglo XIX, Mexico, Fondo de Cultura Económica, 694 p.

Aparicio Frances R. and Jàquez Candida (2003) Musical Migrations: Transnationalism and Cultural Hybridity in Latin/o America, New York, Palgrave Macmillan, $224 \mathrm{p}$.

Appadurai Arjun (1996) Modernity At Large: Cultural Dimensions of Globalization, Minneapolis, University of Minnesota Press, 229 p.

Apprill Christophe (2015) « One step beyond ». La danse ne circule pas comme la musique, Géographie et cultures, 96, pp. 131-150.

Aterianus-Owanga Alice (2018) Le tànnëbéer multisitué. Danses et communauté émotionnelle des fêtes sénégalaises en migration, Socio-anthropologie, 38, pp. 89-108.

Aterianus-Owanga Alice (2017) « Le rap ça vient d'ici! » Musiques, pouvoir et identité dans le Gabon contemporain, Paris, Éditions de la MSH.

Aterianus-Owanga Alice et Guedj Pauline (2014) « On the Waves of the Ocean ». Des musiques dans l'Atlantique noir, Cahiers d'études africaines, 216 (4), pp. 865-887. 
Barth Fredrik (1978) Scale and social organization, Oslo, Universitetsforlaget.

Bauman Zygmunt (2013) La vie liquide, Paris, Hachette.

Becker Howard (1988 [1982]) Les mondes de l'art, Paris, Flammarion.

Bhabha Homi K. (1990) Nation and Narration, London, Routledge, 333 p.

Buckland Theresa Jill (2007) Dancing from Past to Present: Nation, Culture, Identities, University of Wisconsin Press.

Capone Stefania et Salzbrunn Monika (Eds.) (2018) À l'écoute des transnationalisations religieuses/Sounding religious transnationalism, Civilisations, 67, pp. 11-21.

Castaldi Francesca (2006) Choreographies of African Identities: Négritude, Dance, and the National Ballet of Senegal, Urbana, University of Illinois Press.

Chasteen John Charles and Castro-Klarén Sara (Eds.) (2003) Beyond Imagined Communities: Reading and Writing the Nation in Nineteenth-Century Latin America, Washington, Woodrow Wilson Center Press, $280 \mathrm{p}$.

Dankworth Linda E. and David Ann R. (Eds.) (2014) Dance Ethnography and Global Perspectives: Identity, Embodiment, and Culture, New York, Palgrave-Macmillan.

Davis Kathy (2015) Dancing Tango, Passionate Encounters in a Globalizing World, New York, New York University Press, $223 \mathrm{p}$.

Djebbari Elina (2019) Dance, Music Videos and Screens: Intermediality and Videochoreomorphosis in Mali and Benin, Critical African Studies, 11 (1), pp. 87-102.

Djebbari Elina (2018) Vidéochoréomorphose : Danses et vidéo-clips au Mali, Volume! La revue des musiques populaires, 14 (2), pp. 137-159.

Djebbari Elina (2013) Le Ballet National du Mali: créer un patrimoine, construire une nation. Enjeux politiques, sociologiques et esthétiques d'un genre musico-chorégraphique, de l'indépendance du pays à aujourd'hui, Thèse de doctorat en Musique, histoire, société sous la direction d'Estebán Buch et d’Emmanuelle Olivier, Paris, École des Hautes Études en Sciences Sociales.

Franco Susanne (2015) Reenacting Heritage at Bomas of Kenya: Dancing the Postcolony, Dance Research Journal, 47 (2), pp. 3-22.

Gellner Ernest (1989 [1983]) Nations et nationalisme, Paris, Payot.

Gibert Marie-Pierre (2014) Façonner le corps, régénérer l'individu et danser la nation, Parcours anthropologiques, 9, pp. 189-219.

Glick Schiller Nina, Basch Linda and Blanc-Szanton Suzanne (Eds.) (1992) Towards a transnational perspective on migration: race, class, ethnicity and nationalism reconsidered, New York, New York Academy of Science.

Glick Schiller Nina and Çağlar Ayşe (Eds.) (2011) Locating Migration. Rescaling Cities and Migrants, Cornell University Press.

Glick Schiller Nina and Fouron Georges Eugene (2001) Georges Woke up Laughing. Long-Distance Nationalism and the Search for Home, Durham/London, Duke University Press, 326 p.

Goyal Yogita (2017) Introduction: The Transnational Turn, in Yogita Goyal Ed., The Cambridge Companion to Transnational American Literature, New York and Cambridge, Cambridge University Press, pp. 1-17. 
Guillebaud Christine (2014) L'art de la multimodalité : Musique, image et danse en Inde, Anthropologie et Sociétés, 38 (1), pp. 25-45.

Guss David M. (2000) The festive state: race, ethnicity, and nationalism as cultural performance, Berkeley-London, University of California Press.

Hébrard Véronique (1996) Le Venezuela indépendant. Une nation par le discours. 1808-1830, Paris, L'Harmattan.

Hiller Harry H. and Tara M. Franz (2004) New ties, old ties and lost ties: the use of the internet in diaspora, New Media Society, 6, pp. 731-752.

Hobsbawm Eric (1992) Nations et nationalisme depuis 1780, Paris, Gallimard.

Hobsbawm Eric et Terence O. Ranger (2006 [1983]) L'invention de la tradition, Paris, Éditions Amsterdam.

Hughes-Freeland Felicia (2008) Embodied Communities: Dance Traditions and Change in Java, Berghahn Books.

Ignacio Emily Noelle (2005) Building Diaspora: Filipino Cultural Community Formation on the Internet, New Brunswick, NJ, Rutgers University Press, 176 p.

Jung Eun-Young (2014) Transnational Migrations and YouTube Sensations: Korean Americans, Popular Music, and Social Media, Ethnomusicology, 58 (1), pp. 54-82.

Kastoryano Riva (2006) Vers un nationalisme transnational : Redéfinir la nation, le nationalisme et le territoire, Revue française de science politique, 56 (4), pp. 533-553.

Kiwan Nadia and Ulrike Hannah Meinhof (2011) Cultural Globalization and Music: African Musicians in Transnational Networks, Basingstoke, Palgrave Macmillan, 273 p.

Le Menestrel Sara (Dir.) (2012) Des vies en musique. Parcours d'artistes, mobilités, transformations, Paris, Hermann, 316 p.

Laguerre Michael S. (2009) The Transglobal Network Nation: Diaspora, Homeland, and Hostland, in Eliezer Ben-Rafael and Yitzhak Sternberg Ed., Transnationalism: Diasporas and the Advent of a New (Dis)Order, Leiden, Brill Academic Publishing, pp. 195-212.

Lysloff René T. A. (2003) Musical Community on the Internet: An Online Ethnography, Cultural Anthropology, 18 (2), pp. 233-263.

Martiniello Marco, Puig Nicolas et Suzanne Gilles (2009) Créations en migrations, parcours, déplacements, racinement, Revue Européenne des Migrations Internationales, 25 (2), pp. 7-140.

Minard Philippe (2013) Globale, connectée ou transnationale : les échelles de l'histoire, Esprit, 12, pp. 20-32.

Navarro Cécile (2019) «Ce n'est pas le hip-hop qui nous fait voyager, c'est nous qui faisons voyager le hiphop »: Représentations et pratiques d'(im)mobilités au sein d'une scène musicale translocale au Sénégal, Thèse de doctorat en Sciences Sociales sous la direction de Monika Salzbrunn, Université de Lausanne.

Neveu-Kringelbach Hélène and Skinner Jonathan (2012) Dancing Cultures: Globalization, Tourism and Identity in the Anthropology of Dance, Berghahn Books.

Novak David (2011) The Sublime Frequencies of Old New Media, Public Culture, 23 (3), pp. 603-634. 
Ortar Nathalie, Salzbrunn Monika et Stock Mathis (Éds.) (2018) Migrations, circulations, mobilités. Nouveaux enjeux épistémologiques et conceptuels à l'épreuve du terrain, Aix-en-Provence, Presses Universitaires de Provence.

Perry Marc D (2008) Global Black Self-Fashionings: Hip Hop As Diasporic Space, Identities: Global Studies in Culture and Power, 15 (6), pp. 635-664.

Pietrobruno Sheenagh (2006) Salsa and Its Transnational Moves, New York, Lexington Books.

Portes Alejandro, Guarnizo Luis E. and Landolt Patricia (1999) The study of transnationalism: pitfalls and promise of an emergent research field, Ethnic and Racial Studies, 22 (2), pp. 217-237.

Pries Ludger (1996) Transnationale soziale Räume. Theoretisch-empirische Skizze am Beispiel der Arbeitswanderungen Mexico-USA, Zeitschrift für Soziologie, 25 (6), pp. 456-472.

Raibaud Yves (2015) Jalons pour une géographie de la danse, Géographie et cultures, 96, pp. 5-24.

Raout Julien (2009) Au rythme du tourisme. Le monde transnational de la percussion guinéenne, Cahiers d'études africaines, 193-194, pp. 175-202.

Reed Daniel B. (2016) Abidjan USA: Music, Dance and Mobility in the Lives of Four Ivorian Immigrants, Bloomington, Indiana University Press.

Revel Jacques (Dir.) (1996) Jeux d'échelles. La micro-analyse à l'expérience, Gallimard-Seuil-EHESS.

Sainsaulieu Ivan, Salzbrunn Monika et Amiotte-Suchet Laurent (Éds.) (2010) Faire communauté en société. La dynamique des appartenances collectives, Presses Universitaires de Rennes.

Salzbrunn Monika (2019) Islam (in)audible en ville : pluralité religieuse et engagement politique dans l'Arc Lémanique, in Talia Bachir-Loopuyt et Anne Damon-Guillot Éds., Une pluralité audible? Mondes de musique dans la ville, Tours, Presses Universitaires François Rabelais, pp. 179-200.

Salzbrunn Monika (2017) Musique, religion, appartenances multiples : une approche de l'événement, Sociétés Plurielles : Les sciences humaines et sociales à l'épreuve de l'événement, 1, pp. 1-26, [en ligne]. URL : https://societes-plurielles.episciences.org/3668/pdf

Salzbrunn Monika (2016) Shifting Theories, Methods and Topics. Monika Salzbrunn Talks with Ludger Pries about Thirty Years of Migration Studies, Revue Européenne des Migrations Internationales, 32 (3-4), pp. 231-247.

Salzbrunn Monika (2011) Rescaling Processes in two "Global" Cities: Festive Events as Pathways of Migrant Incorporation, in Nina Glick Schiller and Ayşe Çağlar Eds., Locating Migration. Rescaling Cities and Migrants, Ithaka, Cornell University Press, pp. 166-189.

Santos-Febres Mayra (1997) Salsa as Translocation, in Celeste Fraser Delgado and Jose Munoz, Everynight Life: Culture and Dance in Latin/o America, Durham, NC: Duke University Press, pp. 175-188.

Sechehaye Hélène et Weisser Stéphanie (2018) « En Belgique, il n'y a rien » ? Le rituel de la lỉla chez les Gnawa maroxellois, Civilisations, 67, pp. 81-98.

Shay Anthony (2002) Choreographic Politics: State Folk Dance Companies, Representation, and Power, Middletown, CT, Wesleyan University Press.

Shipley Jesse Weaver (2013) Transnational circulation and digital fatigue in Ghana's Azonto dance craze, American Ethnologist, 40 (2), pp. 362-381.

Stokes Martin (2010) The Republic of Love: Cultural Intimacy in Turkish Popular Music, Chicago, University of Chicago Press. 
Stokes Martin (1994) Introduction, in Martin Stokes Ed., Ethnicity, Identity and Music. The Musical Construction of Place, Berg, Oxford/New York, pp. 1-27.

Thiesse Anne-Marie (2014) Nations, internationalismes et mondialisation, Romantisme, 163, pp. 15-27.

Thiesse Anne-Marie (1999) La création des identités nationales, Europe XVIII-XXème siècle, Paris, Seuil.

Trémon Anne-Christine (2012) Que faire du couple local/global ? Pour une anthropologie pleinement processuelle, Anthropologie Sociale, 20, pp. 250-266.

Turner Victor (1987) The Anthropology of Performance, New York, PAJ Publications.

Waxer Lise (Ed.) (2002) Situating Salsa: Global Markets and Local Meaning in Latin American Popular Music, New York, Routledge, 350 p.

Wimmer Andreas and Glick Schiller Nina (2002) Methodological nationalism and beyond: nationstate building, migration and the social sciences, Global Networks, 2 (4), pp. 301-334.

Wulff Helena (2005) Memories in Motion: The Irish Dancing Body, Body \& Society, 4, pp. 45-62.

\section{NOTES}

1. Other studies have already made this observation (Wulff, 2005; Pietrobruno, 2006; Kiwan and Meinhof, 2011; Neveu and Skinner, 2012; Dankworth and David, 2014).

2. This dossier presents an extension of the reflections that took place during the international conference Orchestrating the Nation: Music, Dance and (Trans-)Nationalisms, organised by Alice Aterianus-Owanga and Elina Djebbari on 12 and 13 November 2015 at the Maison des Cultures du Monde in Paris.

3. In 1999, Portes, Guarnizo and Landolt proposed to distinguish these migratory phenomena from classic migrations or older forms of crossing national borders (Portes et al., 1999: 219).

4. For more information on the historicity of this expression, see Goyal (2017).

5. The concept of scale has taken on a new meaning in recent decades: from a spatial and ontological definition, social sciences have shifted to a relational, processual and social definition of scale (Barth, 1978; Trémon, 2012), helping to overcome local/global or national/transnational dichotomies.

6. See Salzbrunn and Pries (2016).

7. Gibert (2014), Clouet (2018), Aterianus-Owanga (2018) and Navarro (2019). The study on the transnationalisation of the religious through music also provided an opportunity to discuss the links between musical practices, transnationalisms and identities. A recent issue of the journal Civilisations dedicated to "Sounding religious transnationalism" (Capone and Salzbrunn, 2018) describes these phenomena of migration of people, instruments, rituals and musical creations as a contribution to the renewal of religious practices and the invention of new identity configurations.

8. This difference can be explained by the fact that in France, ethnomusicology has been recognised for several decades in academic institutions as a disciplinary field in its own right, while the anthropology of dance emerged later and has remained under-represented.

9. See Martiniello et al. (2008), Le Menestrel (2012), Aterianus-Owanga and Guedj (2014), Andrieu and Olivier (2017) and Capone and Salzbrunn (2018).

10. Technological advances in the field of audio-visual recordings, particularly through smartphones, have also led to an exponential development of video-clip productions to accompany the online promotion of artists. The use of images in music has thus promoted dances to new visual roles, through processes of "videochoreomorphosis" (Djebbari, 2018). 


\section{INDEX}

Palabras claves: danza, música, actuación, transnacional, nacionalismo, translocal, circulación, arraigo, identidades, emociones, pertenencia

Mots-clés: danse, musique, performance, transnational, nationalisme, translocal, circulations, ancrage, identités, émotions, appartenance

Keywords: dance, music, performance, transnational, nationalism, translocal, circulations, anchorage, identities, emotions, belonging

\section{AUTHORS}

\section{ALICE ATERIANUS-OWANGA}

Maître Assistante, Ambizione Programme, ISSR, University of Lausanne, Bâtiment Anthropole 5088, Quartier Dorigny, 1015 Lausanne, Switzerland; aliceaterianus@yahoo.fr

\section{ELINA DJEBBARI}

Researcher and teaching assistant in Ethnomusicology, Paris 8 University, MUSIDANSE, 2 rue de la Liberté, 93200 Saint-Denis; elina.djebbari@kcl.ac.uk

\section{MONIKA SALZBRUNN}

Sociologist and anthropologist, Professor of Religions, Migration, Diasporas and Director of the ERC ARTIVISM project, University of Lausanne, Anthropole 5067, 1015 Lausanne, Switzerland; monika.salzbrunn@unil.ch 